\title{
SUPEREU: A VOZ DE UM IMPERATIVO INTERROMPIDO
}

\author{
SUPEREGO: THE VOICE OF AN INTERRUPTED IMPERATIVE
}

SUPERYÓ: LA VOZ DE UN IMPERATIVO INTERRUMPIDO

\author{
Geisa Karla Oliveira de Assis* \\ Marcus André Vieira ${ }^{* *}$
}

\begin{abstract}
RESUMO
O objetivo deste trabalho é estudar o supereu, percorrendo os caminhos que nos levam a ele como voz de um imperativo interrompido. Buscamos demonstrar que o supereu não está referido às identificações que norteiam o sujeito, mas sim a comandos desnorteadores. Para isso, abordamos o Édipo, a instância crítica e o conceito lacaniano de objeto $a$, em sua substância episódica vocal. Com relação ao Édipo, afirma-se que seu herdeiro é o ideal do eu, e não o supereu. Com relação à instância crítica, demonstrou-se que, já em Freud, as funções supereuoicas são abordadas em um além do Édipo. E, por fim, com o conceito de objeto $a$ voz, foi possível demarcar a dimensão pulsional da voz descolada de identificação, que não norteia, mas ordena a partir de um imperativo interrompido que reclama obediência e submissão. Essa voz que exprime o supereu ao vociferar seu imperativo: "Goza!".
\end{abstract}

Palavras-chave: Supereu. Complexo de Édipo. Objeto $a$. Voz. Imperativo.

\begin{abstract}
The aim of this work is to study the superego treading along the paths that lead us to it as the voice of an interrupted imperative. We mean to demonstrate that the superego is not referred to the identifications that guide the subject, but to disorientating commands. For this purpose, we approached the Oedipus, the critical instance and the Lacanian concept of object $a$, in its vocal episodic substance. Regarding Oedipus, it states that its heir is the ideal of the self, not the superego. Regarding the critical instance, it was shown that in Freud indeed, the superego functions are addressed in an instance beyond Oedipus. In addition, finally, with the concept of the $a$ object voice it was possible to delimit the instinctual dimension of voice deprived of identification, which does not guide, but commands from an interrupted imperative that demands obedience and submission. The voice that expresses the superego uttering its imperative: "Enjoy".
\end{abstract}

\footnotetext{
Texto recebido em 7 de março de 2016 e aprovado para publicação em 27 de julho de 2016.

*Especializanda em Clínica Psicanalítica pelo IPUB/UFRJ, graduada em Psicologia pela Pontifícia Universidade Católica do Rio de Janeiro (PUC Rio).

* Doutor pela Université de Paris VIII, França, professor doutor adjunto do Programa de Pós-Graduação em Psicologia Clínica - PUC Rio, psicanalista. Endereço: Rua Mapendi, 144, bl. 2. Ap. 202 - Taquara, Rio de Janeiro-RJ, Brasil. CEP: 22710-255. E-mail: geisakassis@yahoo.com.br.
} 
Keywords: Superego. Oedipus complex. Object. Voice. Imperative.

\section{RESUMEN}

El objetivo de este trabajo es estudiar el superyó, cruzando los caminos que conducen a él como la voz de un imperativo interrumpido. Se demuestra que el superyó no se hace referencia a las identificaciones que guían el tema, pero los comandos desconcertantes. Para esto, abordamos el Edipo, la instancia crítica y el concepto lacaniano del objeto en su sustancia episódica vocal. Con respecto al Edipo, afirma que su heredero es el ideal del yo, no el superyó. En relación a la instancia crítica, se demostró que ya en Freud, las funciones del superyó se tratan en un más allá de Edipo. Y, por último, con el concepto del objeto voz era posible delimitar la dimensión instintiva de la voz de identificación cobarde, que no guía, pero las órdenes de un imperativo detenido que exige la obediencia y la sumisión. Esa voz que expresa el superyó al echar bravatas su imperativo: "Disfruta!".

Palabras-clave: Superyó. Complejo de Edipo. Objetar. Voz. Imperativo.

\section{IDEAL DO EU: HERDEIRO DO COMPLEXO DE ÉDIPO}

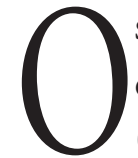

supereu é uma instância que, juntamente com as instâncias do eu e do isso, forma a segunda tópica freudiana do aparelho psíquico. Freud $(1923 / 2007)^{3}$ estabelece sua diferenciação conceitual, designando-o como herdeiro do complexo de Édipo por comportar os primeiros investimentos do isso. Isso o aproxima mais do isso e o afasta do eu e da consciência. Sua relação com o eu se assemelha a um juiz ou censor que o domina, toma-o por objeto, criticando-o, depreciando-o e julgando-o.

O conflito, portanto, será um traço marcante na relação entre o supereu e o eu. Como precipitado dos investimentos objetais abandonados, o supereu comportará a história das escolhas objetais do isso, que é marcada de proibição, assim como afirma Freud (1923): "A história da formação do supereu permite compreender que antigos conflitos entre o eu e os investimentos de carga que o isso depositava nos objetos, prossigam mais tarde na forma de conflitos entre o eu e o herdeiro do isso, o supereu" (p. 48).

É quando Freud aborda os delírios de observação, a melancolia e o luto patológico, em 1915, que ele considera uma diferenciação no seio da personalidade, uma parte do eu levantada contra outra: "Essa instância é inicialmente definida por Freud, nos anos de 1914-15, como um sistema que por sua vez compreende

3 A primeira data indica o ano de publicação original da obra, e a segunda, a edição consultada pelo autor, a qual somente será pontuada na primeira citação da obra no texto. Nas seguintes, será registrada apenas a data de publicação original. 
duas estruturas parciais: o ideal do eu propriamente dito e uma instância crítica” (Laplanche \& Pontalis, 2001, p. 498).

A elaboração teórica do ideal do eu dá-se em Introdução ao narcisismo, em 1914, como uma identificação substituta do narcisismo da infância que é projetado diante de si, um modelo que está sob a tutela de uma instância psíquica especial que deve assegurar a satisfação narcísica, comparar o eu atual ao ideal, estabelecer limites e conceder medidas para a preservação do eu (Freud, 1914/2010). Reiteramos com Lacan sua diferenciação diante do eu ideal: "De fato, o ideal do eu não se propõe - é quase uma obviedade dizê-lo - como um eu ideal" (Lacan, 1957-1958/1986, p. 300).

$\mathrm{Na}$ análise de adultos, Freud reconhece que a grandeza do eu resultante do investimento da libido do eu que outrora dominava na criança se enfraqueceu e seus traços psíquicos se apagaram. Ele não acredita que toda essa libido do eu tenha se convertido em investimentos objetais, mas sim que ao "eu ideal dirigese então o amor a si mesmo, que o eu real desfrutou na infância" (Freud, 1914, p. 40).

Esse amor se dirige ao eu ideal por meio do recalque que ganha um novo agente na teoria psicanalítica, não mais o eu, mas o autorrespeito do eu. Segundo Freud, os impulsos instituais da libido são recalcados quando entram em conflito com os ideais morais e culturais do sujeito. Para que haja o recalque, não basta que esses ideais sejam apenas entendidos intelectualmente pelo sujeito, mas sim devem ser considerados por ele como determinantes, submetendo-se às exigências que partem deles.

O narcisismo se desloca para o eu ideal, achando-se então de posse de toda perfeição. O direcionamento da libido investida no eu ao eu ideal, por causa do recalque, aponta-nos à incapacidade de renúncia à satisfação do sujeito no âmbito da libido. O sujeito não quer abrir mão de sua perfeição narcísica, mas, como não pode mantê-la por causa do recalque, readquire tal satisfação na forma nova do ideal do eu. Assim afirma Freud: "O que ele projeta diante de si como seu ideal é o substituto para o narcisismo perdido da infância, na qual ele era seu próprio ideal" (Freud, 1914, p. 40).

Nesse texto, Freud não diferencia explicitamente eu ideal do ideal do eu. Em um mesmo parágrafo, ele apresenta eu ideal e ideal do eu sem esclarecer alguma diferença entre os dois. Lacan (1953-1954/1986), porém, em seu Seminário 1, pontua algumas diferenças implícitas no texto freudiano.

Primeiramente, Freud não se utiliza da mesma expressão para abordar as duas funçôes. Diz Lacan: "E Freud emprega aí Ich-Ideal (ideal do eu), que é 
exatamente simétrico e oposto ao Ideal-Ich (eu ideal). É o signo de que Freud designa aqui duas funções diferentes" (Lacan, 1953-1954, p. 157).

Segundo, antes de introduzir a expressão ideal do eu, Freud o precede pela expressão forma nova: "Ele não quer se privar da perfeição narcísica de sua infância, e se não pôde mantê-la, perturbado por admoestações durante seu desenvolvimento e tendo seu juízo despertado, procura readquiri-la na forma nova do ideal do eu" (Freud, 1914, p. 40).

Vemos então que o amor de si mesmo é resultante do narcisismo infantil que se constitui graças ao investimento da libido do eu e que pode ser observado na projeção de ideal feito pelos pais na criança, ou seja, o renascimento de seu próprio narcisismo infantil. $\mathrm{O}$ amor de si mesmo é recalcado ao entrar em conflito com os ideais morais e culturais do sujeito, que foram constituídos graças às admoestaçôes feitas à criança ao longo de seu desenvolvimento, sendo então dirigido ao eu ideal que se acha, por isso, de posse de toda perfeição. $\mathrm{O}$ sujeito no âmbito da libido é incapaz de renunciar a satisfação e por isso projeta diante de si o substituto para o seu narcisismo da infância: o seu ideal do eu.

Esse amor de si mesmo se constitui também com base nas escolhas objetais feitas na época do narcisismo. "Dizemos que o ser humano tem originalmente dois objetos sexuais: ele próprio e a mulher que o cria" (Freud, 1914, p. 33). Lacan precisa: "Ele próprio, isto é, sua imagem. É claríssimo" (Lacan, 19531954, p. 154).

O ideal do eu será o responsável por garantir a satisfação narcísica e é o "modelo ao qual o sujeito procura conformar-se" (Laplanche \& Pontalis, 2001, p. 222). Nele tudo é magnífico. "Magnífica é a própria instância do ideal do eu que idealiza as identificações com os atributos amáveis, a partir de um Outro que sempre outorga seu visto positivo" (Gerez-Ambertín, 2003, p. 58).

A carga de investimento depositada no objeto, que no narcisismo é a imagem da criança e a mulher que a cria, foi recolhida e substituída por uma identificação, o ideal do eu. Os efeitos dessas identificações iniciais serão gerais e duradouros, o que levará Freud a formular a preposição de que a origem do ideal do eu está atrás da "primeira e mais significativa identificação do sujeito, aquela com o pai da pré-história pessoal” (Freud, 1923, p. 28). É então na abordagem do complexo de Édipo, mais precisamente em sua saída, e nas identificações que ali são engendradas, que a gênese e o caráter do ideal do eu são apresentados, o que leva Lacan afirmar que "O declínio do Édipo, seu resultado, seu fruto no sujeito [é] a identificação do filho com o pai” (Lacan, 1957-1958, p. 191).

O conteúdo do complexo de Édipo simples e positivo é formado no menino 
pela tomada da mãe como objeto sexual e uma ambivalência para com o pai, resultado da identificação e hostilidade para com ele. Hostilidade, pois o pai é sentido como obstáculo à realização dos desejos edipianos, levando o menino a desejar sua eliminação para ocupar seu lugar junto à mãe.

Para sair do Édipo, o menino deve abandonar o investimento objetal na mãe, intensificando a identificação com o pai, permitindo a conservação da relação com a mãe. Assim, o caráter masculino é fixado no menino, o que nos remete à seguinte afirmação de Lacan: "A virilidade e a feminização são os dois termos que traduzem o que é, essencialmente, a função do Édipo. Encontramo-nos, aí, no nível em que o Édipo está diretamente ligado a função do Ideal do eu - ele não tem outro sentido" (Lacan, 1957-1958, p. 171).

Na saída do complexo de Édipo, os investimentos feitos na mãe e no pai e a identificação para com estes se agruparão e resultarão em uma identificação com a mãe e uma identificação com o pai, a identificação paterna mantendo a relação objetal com a mãe e a materna mantendo a relação objetal com o pai. $\mathrm{O}$ peso das disposições sexuais será refletido na intensidade das identificações. Haverá assim um precipitado no eu composto por essas duas identificaçôes ajustadas, de alguma maneira, uma à outra. Surge, a partir dessa conservação da posição especial do eu, um conteúdo restante, o ideal do eu.

Sendo o conteúdo do ideal do eu aquele que restou da conservação da posição especial do eu, ele relacionar-se-á com o eu não apenas o advertindo, mas também o proibindo. A partir do momento em que o desejo edipiano se intensifica, é necessário que o eu introjete o pai para obstaculizar este desejo, levando ao recalque destes. Essa introjeção resultará no ideal do eu. O ideal do eu encarna então a proibição da satisfação dos desejos edipianos e leva o eu a procurar novos tipos de satisfação.

Em seu movimento de retorno a Freud, Lacan lê o complexo de Édipo e estabelece três tempos. O primeiro é composto pela mãe, o filho e o falo. A mãe, supondo que nada lhe falta, "imaginariza" o filho como falo, e este busca então satisfazer o seu desejo, pois, para agradar a mãe, é "necessário e suficiente ser o falo [. . . ] o sujeito se identifica especularmente com aquilo que é objeto do desejo de sua mãe" (Lacan, 1957-1958, p. 198). Esse tempo é equivalente ao estádio do espelho e ao narcisismo, acima descritos. Aqui o pai aparece como velado, o que não impede sua existência no mundo real.

Já no segundo tempo, o pai aparece como privador mediado pelo discurso da mãe. Ele priva a mãe do falo. Essa privação recai sobre o filho como perda de objeto de desejo, instaurando nele a falta. 
A estreita ligação de esse remeter a mãe a uma lei que não é a dela, mas a de um Outro, com o fato de o objeto de seu desejo ser soberanamente possuído, na realidade, por esse mesmo Outro a cuja lei ela remete, fornece a chave da relação do Édipo. O que constitui seu caráter decisivo deve ser isolado como relação não com o pai, mas com a palavra do pai (Lacan, 1957-1958, p. 199).

A função paterna não é o pai da realidade, mas a eficácia da lei sobre o desejo da mãe e do filho. O pai não é a lei, mas sim aquele que a transmite, em nome do pai. A lei proíbe a relação incestuosa entre mãe (não reintegrarás teu produto) e filho (não dormirás com tua mãe) e possibilita o desejo.

No terceiro tempo, o pai aparece como aquele que pode satisfazer o desejo da mãe, pois tem a chave para tal. Ele intervém como possuidor do falo, possibilitando a identificação do filho para com o pai e, por isso, o estabelecimento do ideal do eu. O filho poderá buscar outros meios de satisfação, já que um lhe é proibido: a mãe. Tal movimento indica a incorporação da lei e a possibilidade do desejo. É porque a mãe falta, porque ela é castrada e não é capacitada a dar todas as coisas à criança, que esta pode desejar outra coisa que não a mãe. Por isso a interdição do incesto é a própria condição de possibilidade da palavra, da habitação da criança no meio simbólico, como afirma Valas (2001):

A interdição do incesto é a própria condição de possibilidade da palavra e é o que a experiência clínica nos ensina. Porque a mãe está em falta, porque ela falta, porque não pode responder de modo inteiramente satisfatório às demandas do sujeito, este pode desejar outra coisa, que ela não está capacitada a lhe dar (Valas, 2001, p. 31).

O ideal do eu, como herdeiro do complexo de Édipo, como depósito do conteúdo restante do complexo de Édipo, é aquele que mantém distante do eu a satisfação do gozo edipiano, graças à identificação para com o pai sentido como obstáculo à realização desse gozo, que permitirá a criança habitar o campo simbólico da lei. Assim, o gozo se torna proibido, podendo apenas ser dito entrelinhas:

O gozo é proibido aquele que fala como tal, porque é a própria condição de possibilidade da palavra. Daí resulta que o gozo só pode ser dito entrelinhas (inter-dito) pelo sujeito da Lei, isto é, pelo sujeito dividido entre o desejo que vem do Outro e o gozo que está na Coisa (Valas, 2001, p. 35).

É por isso que, segundo Lacan (1957-1958), “O complexo de Édipo tem uma função normativa, não simplesmente na estrutura moral do sujeito, nem em suas relações com a realidade, mas quanto à assunção de seu sexo [. . .]" (pp. 170-171). Isso aponta à ação organizadora que o eu sofre na saída do Édipo, 
resultando em uma conservação da posição especial do eu.

Mas Lacan atribui à identificação resultante da saída do Édipo que organiza o eu e o insere no simbólico, não ao supereu, mas sim ao ideal do eu:

Em terceiro lugar, o pai se revela como aquele que tem. É a saída do Complexo de Édipo. Essa saída é favorável na medida em que a identificação com o pai é feita nesse terceiro tempo, no qual ele intervém como aquele que tem o falo. Essa identificação chama-se Ideal do eu (Lacan, 1957-1958, p. 200).

O supereu para Lacan não será concebido como resultante de uma identificação que leva à normatização, mas como a raiz da palavra, a destruição da lei do desejo, palavra privada de todos os sentidos, figura feroz.

O supereu é, a um só tempo, a lei e a sua destruição. Nisso, ele é a palavra mesma, o comando da lei, na medida em que dela não resta mais do que a raiz. A lei se reduz inteiramente a alguma coisa que não se pode nem mesmo exprimir, como o Tu deves, que é uma palavra privada de todos os seus sentidos. É nesse sentido que o supereu acaba por se identificar àquilo que há somente de mais devastador, de mais fascinante, nas experiências primitivas do sujeito. Acaba por se identificar ao que chamo figura feroz, às figuras que podemos ligar aos traumatismos primitivos, sejam eles quais forem, que a criança sofreu (Lacan, 19531954, p. 123).

O supereu para Freud é definido a partir do complexo de Édipo sendo efeito tanto da identificação com o obstáculo externo à realização dos desejos edipianos, necessário para o recalque do complexo de Édipo, quanto efeito desse mesmo recalque, por isso nomeado por Freud como o herdeiro do complexo de Édipo, tornando-se responsável por advertir e proibir o eu, como nos afirma Freud (1923):

O Supereu não é apenas um resíduo das primeiras escolhas objetais do Id; ele representa também uma enérgica formação reativa contra essas escolhas. Sua relação com o Eu não se esgota na advertência: "Você deve ser assim (como seu pai)", mas engloba também a proibição: "Você não pode ser assim (como seu pai)"; isto é, você não pode fazer tudo o que ele faz, algumas coisas permanecem prerrogativa dele (Freud, 1923, p. 44).

Tais ações as quais Freud coloca sob a rubrica do supereu dão ao eu um direcionamento: isso você deve fazer, isso você não pode fazer. Logo o eu está referido a um modelo que direciona seu gozo, ou seja, normatiza-o, a partir da identificação com o obstáculo à realização dos desejos edipianos, o pai como portador do falo. Essa é a tarefa que a saída do complexo de Édipo deve exercer e que fica sob a tutela do supereu, herdeiro do complexo de Édipo, segundo Freud. Porém o supereu não é resultado dessa identificação, como nos afirma Gerez- 
Ambertín (2003): "Se o supereu fosse somente o resultado de uma operação identificatória, sua abordagem na clínica e no mal-estar na civilização não seria tão espinhosa” (p. 58).

Segundo a extração feita por Lacan de Freud, essa identificação é o ideal do eu. O menino só sai do Édipo, pois se identifica com o pai, que porta o falo. Para Lacan, a identificação decorrente do Édipo é o Ideal do eu. É essa identificação que permitirá ao menino sair da relação de alienação com a mãe e habitar o campo do simbólico. A diferenciação aqui proposta não é uma questão de nomeação, mas sim das funções que cada instância desempenha no psiquismo.

O supereu, para Lacan, é aquilo que representa exatamente o que o complexo de Édipo não recobre em termos de identificação e normatização, pois o Édipo fracassa em alguma medida. Aquilo que não é recoberto pela identificação decorrente do Édipo, ou seja, o que não é recoberto pelo Ideal do eu, já era assinalado por Freud em seu texto Luto e melancolia, no qual ele situava uma instância crítica na melancolia, que envolveria uma identificação mais primitiva que as identificações do ideal do eu (Freud, 1915/2010).

\section{SUPEREU: ALÉM DO ÉDIPO}

Como vimos, o ideal do eu é uma identificação substituta do narcisismo da infância, identificação resultante do complexo de Édipo, o seu verdadeiro herdeiro. É essa identificação, o ideal do eu, que é projetado diante do eu, sendo uma identificação secundária, um modelo que está sob a tutela de uma instância psíquica especial que deve assegurar a satisfação narcísica comparando o eu atual ao ideal.

Porém essa instância apresenta uma contrapartida que, segundo GerezAmbertín (2003), divide-se em um Eu crítico, que, em 1923, receberá o nome de supereu, e um Eu alterado pela identificação. Em ambos, há crítica e subjugação. A identificação secundária, o ideal do eu, oferece à instância que puramente crítica e subjuga uma sombra imaginária, que é sustentada pelos suportes idealizantes. Porém há algo nesse objeto que é amado, odiado e temido ao sustentar os efeitos imaginários: "Uma sombra tutelar, que deixa como causa um resto estranho, improcessável e inassimilável” (Gerez-Ambertín, 2003, p. 63).

Essa instância que deixa como causa um resto estranho, improcessável e inassimilável é formulada por Freud (1915) com o nome de "instância crítica". É a instância crítica que comporta o inassimilável da relação objetal e a utiliza contra o próprio eu, ou melhor, contra a parte do eu modificada pela identificação do eu para com o objeto perdido. 
A instância crítica se apresenta na melancolia como uma instância autônoma e dissociada do eu que toma e dirige ao eu os sentimentos de ódio que este dispensava ao objeto perdido, a partir da identificação empreendida com o objeto, para não perder sua relação amorosa, comportando-se de maneira hostil.

A necessidade da conceituação da instância crítica apresenta toda sua força na melancolia, pois a crueldade que essa instância apresenta não é comportada nas identificações secundárias do ideal do eu. A crueldade da instância crítica é assim, pois ela é decorrente de uma identificação primitiva, de caráter oral e canibal, tornando algo improcessável nessa instância. A instância crítica é a instância que está para além do jogo das identificações que originam o ideal do eu ou como afirma Gerez-Ambertín (2003), ela está relacionada às identificações primordiais.

$\mathrm{Na}$ melancolia, podemos ver ilustrada a severidade e crueldade do supereu. Nela há um empobrecimento do eu, revelando um rebaixamento da autoestima expressado por recriminaçôes e ofensas ao próprio sujeito e uma espera por castigo. O eu se sente pobre, vazio, indigno, incapaz e desprezível, recrimina e insulta a si mesmo e espera rejeição e punição. Esse "delírio de pequenez predominante moral" (Freud, 1915, p. 176) é completado por uma "psicologicamente superação do instinto que faz todo vivente se apegar à vida" (Freud, 1915, p. 176), ou como afirma Freud, "o que vigora no Supereu na melancolia é uma pura cultura da pulsão de morte” (Freud, 1923, p. 60).

Freud considera que esse delírio de pequenez predominante moral na verdade é uma parte do eu que se levanta contra outra, contrapondo-se a ela, realizando sobre ela uma avaliação crítica e tomando-a por objeto. Essa parte é autônoma e, por isso, dissociada do eu. "Realmente encontraremos motivo para separar essa instância do resto do Eu" (Freud, 1915, p. 178).

Há também um doloroso infortúnio na melancolia que se refere à substituição de um investimento objetal por uma identificação. A libido livre de um investimento objetal, em vez de se ligar a um outro objeto, volta-se ao eu e lá estabelece uma identificação com o objeto abandonado. A partir daí, e aqui se configura a gênese da instância crítica, o eu pode ser julgado por uma instância como um objeto, aquele que foi abandonado. "Assim, a sombra do objeto caiu sobre o eu, e a partir de então este pôde ser julgado por uma instância especial como um objeto, o objeto abandonado" (Freud, 1915, p. 181).

O supereu, que tinha sua gênese localizada a partir do Édipo, pode agora ser considerado fruto de identificaçóes primárias, arcaico e responsável pela constituição do sujeito primordial, podendo ser tomado como núcleo do próprio eu: "O supereu, que havia surgido na posição de herdeiro do complexo de Édipo, 
passará também a primário, a ponto de ser tomado como núcleo do próprio eu" (Rudge, 2006, p. 82).

Por isso o supereu não pode ser reduzido ao campo das identificações, pois "se trata de um além do inconsciente que se ancora somente na identificação fundadora do sujeito" (Gerez-Ambertín, 2003, p. 64).

Também para Gerez-Ambertín (2003), a instância crítica só pode se relacionar com a identificação primária, constitutiva do sujeito primordial e, por isso, seria "Resistente à dialética identificatória e histérica. O intrusivo da incorporação, propenso à fixação, torna-se improcessável e inassimilável à lógica das substituiçōes" (Gerez-Ambertín, 2003, p. 64).

Porém podemos nos perguntar sobre a atribuição do supereu como uma identificação. Como pode uma identificação ser resistente à dialética identificatória? Na melancolia, vimos com Freud que a instância crítica é formada a partir da incorporação do objeto perdido "conforme a fase oral ou canibal do desenvolvimento da libido, por meio da devoração" (Freud, 1915, p. 182). Essa identificação, portanto, não produz separação entre o eu e o Outro, como ocorre com a emergência do ideal do eu, na saída do complexo de Édipo. Pelo contrário, a incorporação do objeto perdido na melancolia resultará na formação de uma nova instância para que o eu seja castigado, como o objeto perdido seria. Não há separação entre o eu e o Outro, mas sim assimilação do Outro, do exterior no interior, tornando este agora estranho.

Freud, buscando evitar a redução do supereu à lógica identificatória, afirma que o supereu da criança se edifica segundo o supereu dos pais e não segundo os pais: "O Supereu da criança é construído não segundo o modelo dos pais, mas do Supereu dos pais" (Freud, 1933/2010, p. 205). Gerez-Ambertín (2003) também afirma que, se o supereu fosse apenas resultado de identificação, sua abordagem não seria tão espinhosa:

Deve-se ter cautela ao extremo e diferenciar com precisão a dialética identificatória da instância demoníaca. Se o supereu fosse somente o resultado de uma operação identificatória, sua abordagem na clínica e no mal-estar na civilização não seria tão espinhosa (GerezAmbertín, 2003, p. 58).

Nas formulações psicanalíticas, há uma dificuldade em dizer que essa identificação canibal e oral que ocorre por meio de devoração e incorporação seja mesmo uma identificação. A saída que muitos autores encontraram foi adjetivar o supereu como materno, para diferenciar do ideal do eu que seria paterno, sujeito à dialética identificatória. 
Vimos que essa zona já é apontada por Freud quando ele fala de uma instância crítica, que envolve uma dita identificação mais primitiva que as identificações do ideal do eu. Isso fornece a essa instância certa independência em relação ao ideal do eu, independência que será atribuída ao supereu.

O ideal do eu, como identificação secundária que recobre o resto inassimilável da instância crítica demais, visa a manter a suficiência simbólica do Outro. Já a instância crítica, resultado da divisão promovida no eu pela identificação com o objeto perdido que tem como função julgar o eu como o objeto, apresenta-nos, segundo Barros (1997), "A relação do sujeito com essa insuficiência simbólica do Outro, que se manifesta de forma clara com o imperativo superegoico" (p. 33).

Dizer que o supereu é materno, precoce ou primitivo aponta para a existência de uma zona no sujeito que não é compreendida pelo Édipo, que não é recoberta por sua identificação, o ideal do eu, ou seja, aponta para as falhas da estrutura, a insuficiência do Outro e não para aquilo que supostamente o supereu carrega de materno ou primeiro. Chamar o supereu de materno, primitivo ou primevo não significa que este é maternal ou que vem primeiro na constituição do aparato psíquico, mas sim que o supereu não está referido à identificação fálica que dirige e contorna o sujeito.

Além disso, atribuir adjetivos ao supereu parece ineficaz, segundo GerezAmbertín (2003):

Para o supereu, a adjetivação de materno ou paterno, edípico ou pré-edípico, resulta absolutamente ineficaz. O importante é que ele surge como objeto resto da divisão do sujeito ante o Outro e, como resíduo, sempre ficará à espreita da subjetividade recordandolhe a inconsistência desse Outro [. . . em resumo, os pecados da estrutura (p. 228).

O supereu, que tinha sua gênese localizada a partir do Édipo, pode agora ser considerado efeito de identificaçóes primárias, arcaico e responsável pela constituição do sujeito primordial, podendo ser tomado como núcleo do próprio eu.

É por isso que a independência atribuída ao supereu, em Lacan, não se faz por meio da ideia de este ser herdeiro de uma identificação, mas sim, por meio da noção de objeto $a$, objeto resto da divisão do sujeito ante o Outro, e de imperativo, uma exigência sem conteúdo e direção.

\section{SUPEREU E OBJETO $A$ VOZ}

Abordaremos agora o supereu com base em sua íntima relação com o objeto a lacaniano, pois assim como o supereu, o objeto $a$ se impóe como um modo de 
gozo. Segundo Vieira (2008):

Quando falta ao Outro um desejo definido, suas demandas se tornam exigências sem perfil, pura inconsciência constituída como tal, puro capricho, sempre excessivo. O supereu, para Lacan é, [. . . ] pura exigência de satisfação que diz “Goza!". A esse supereu está articulado o objeto a, pois ele também se impõe como satisfação (p. 174).

Mas é à voz, como objeto $a$, que o supereu se articula, sendo sua concepção apenas válida quando levada em consideração essa ligação evidente, como nos alerta Lacan (1962-1963/2005): "Ao lembrar-lhes sua ligação evidente com a forma de objeto a que é a voz, indiquei-lhes que não pode haver concepção analítica válida do supereu que se esqueça de que, por sua fase mais profunda, essa é uma das formas do objeto $a "$ (p. 321).

Lacan atribuirá ao supereu um imperativo, transformando-o em uma exigência sem contorno. Esse imperativo se presentifica como uma voz desencarnada e difusa que não é experimentada como vindo de uma pessoa, mas que é atribuída à voz do Outro. Essa atribuição da voz ao Outro é o que caracteriza a dimensão da voz como objeto $a$, como afirma Miller (2013, p. 11): "A voz aparece em sua dimensão de objeto quando é a voz do Outro".

Segundo Lacan, o supereu, imperativo do gozo e as vozes das alucinaçôes do psicótico nos levam a conhecer uma das formas de seu objeto $a$. Trata-se aqui da emergência do objeto $a$ voz que, dentro da teoria de objeto de Lacan, apresentarse-á como uma voz desincorporada:

De que objeto se trata? Daquilo a que chamamos voz. Nós o conhecemos bem, acreditamos conhecê-lo bem, a pretexto de conhecermos seus dejetos, as folhas mortas, sob a forma das vozes perdidas da psicose, e seu caráter parasitário, sob a forma dos imperativos interrompidos do supereu (Lacan, 1962-1963, p. 275, grifo nosso).

\section{A INCORPORAÇÃO DA VOZ}

Para entendermos a voz como desincorporada, presença de uma exigência maciça, trataremos primeiro daquilo que Lacan denominou "incorporação da voz”. Aqui diferenciaremos a incorporação da voz do objeto a voz, sendo a primeira a possibilidade de fala pelo sujeito, por meio da alienação à voz do Outro.

Lacan (1957-1958), no seminário 5, abordou a operação da alienação ao desejo do Outro por meio da fala. Para que o sujeito tome a sua fala como própria, é necessário que, primeiro, ele se aliene à voz do Outro e, segundo, que ele não seja todo alienado pela voz do Outro, ou seja, que ele perca algo 
da sua voz para poder falar. Seguiremos com Lacan e abordaremos o processo de alienação à voz do Outro pelo sujeito por meio daquilo que ele nomeou invocação: "A invocação exige, é claro, uma dimensão inteiramente diversa, ou seja, que eu faça meu desejo depender do teu ser, no sentido de te convidar a entrar na via desse desejo, seja ele qual for, de maneira incondicional" (Lacan, 1957-1958, p. 157).

Aqui vemos Lacan afirmar que o ato da invocação exige que "eu faça meu desejo depender do teu ser". A possibilidade de desejo pelo sujeito somente se dá se, primeiro, este depender do Outro, fazendo-o entrar na via do desejo de maneira incondicional. Assim, o sujeito só pode invocar se alienando à voz do Outro.

Lacan não toma a invocação como uma conversa com Deus, mas como produção da fala no sujeito na relação com o semelhante, na paradigmática relação mãe-bebê, por exemplo, quando o bebê começa a apelar para mãe.

Aqui, Lacan reduz o caráter místico-religioso do termo invocação afirmando que o que importa é você ganhar a voz do Outro. O "eu sou" só poderá ser proferido pelo sujeito se antes ele passar pelo Outro, sendo mergulhado pelo "tu és" que ele lhe atribui. O sujeito só se torna um ser de linguagem passando pelo Outro. Logo, o sujeito só fala, só invoca e apela para o Outro depois de passar pela voz dele, tomando-a como própria.

Através da invocação, é claro, é a impenetrabilidade pessoal subjetiva que fica implicada, mas não é nesse nível que procuramos atingi-la. O que está em causa em qualquer invocação? A palavra invocação tem um emprego histórico. Ela é o que se produzia numa certa cerimônia que os antigos, que tinham mais sabedoria do que nós quanto a certas coisas, praticavam antes do combate. Essa cerimônia consistia em fazer o que fosse preciso - eles sabiam o que era, provavelmente - para colocar a seu lado os deuses dos outros. É exatamente isso que quer dizer a palavra invocação, e é nisso que reside a relação essencial, à qual os remeto agora, dessa etapa secundária, a do apelo, necessária para que o desejo e a demanda sejam satisfeitos [.. . ]. É no nível da fala, e por se tratar de que essa voz se articule de conformidade com nosso desejo, que a invocação se coloca (Lacan, 1957-1958, p. 159).

Vejam que, nessa passagem, Lacan não está falando de Deus ou de invocação religiosa, apesar de citar a palavra deuses. Ele está falando de uma situação que ocorre na relação com o semelhante.

É na invocação que reside a relação especial com o apelo, sendo este necessário para que o desejo e a demanda sejam satisfeitos. Ou seja, o sujeito somente apelará ao Outro, passo fundamental para a satisfação do desejo e da demanda, se ele invocar, colocar a voz do Outro para dentro de si, tornando-a sua, pois, antes, nem apelar o sujeito sabia. Ele aprende tudo com o Outro, inclusive a 
apelar.

Há, portanto, uma parte do sujeito que falta e fica de lado, uma voz que ele teria se tivesse sua voz inteira, pois agora, como vimos, ele não apela com a sua própria voz, com a sua voz inteira, mas somente com a invocação da voz do Outro, a tomada da voz do Outro para dentro de si. A constituição do apelo no sujeito gera um resto que assumiremos ser o objeto $a$ voz. A voz é o resto da operação de fala.

Em vez de ficarmos com o termo invocação para a alienação à voz do Outro, possibilidade de fala pelo sujeito, escolhemos usar o termo incorporação que é o utilizado por Lacan no seminário 10: "Para que ela [a voz] responda, devemos incorporar a voz como a alteridade do que é dito" (Lacan, 1962-1963, p. 300). Para Lacan, "A voz [. . . ] não é assimilada, mas incorporada” (Lacan, 1962-1963, p. 301).

Lacan, em seu seminário 10 , relaciona a constituição do sujeito à incorporação da voz. O sujeito, antes de emergir a questão "quem sou eu?", ouve do Outro, já que é no campo do Outro que estão todos os instrumentos de comunicação, um "tu és". Foi isso que queríamos dizer com o fato de o sujeito só proferir um "eu sou" passando pelo "tu és" do Outro. O Outro só pode proferir o "tu és" ao sujeito se ele portar palavras para isso. Essas palavras são ele próprio, por isso o sujeito só pode vir a ser um sujeito, assumindo a sua voz como própria, passando pelo Outro.

Lacan, já em 1958, antes da construção teórica de seu objeto $a$, fala de uma impenetrabilidade pessoal subjetiva, sendo claro ao dizer que, nessa altura de seu ensino, em seu seminário 5 , não é da impenetrabilidade pessoal subjetiva que se trata, mas sim da invocação que aqui assumimos como incorporação da voz: "Através da invocação, é claro, é a impenetrabilidade pessoal subjetiva que fica implicada, mas não é nesse nível que procuramos atingi-la" (Lacan, 1957-1958, p. 159).

Nossa hipótese é que essa impenetrabilidade pessoal subjetiva é aquilo que ele vai retomar no seminário 10 como objeto $a$, e aqui especificamente objeto $a$ voz, resto real do sujeito que resta antes de ele começar a falar. Há um resto da divisão subjetiva que a entrada na linguagem engendra no sujeito, um resto da operação da linguagem, como vemos no primeiro esquema da divisão, no seminário 10: 


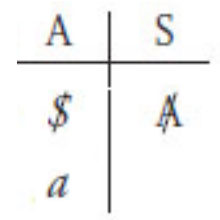

Fonte: (Lacan, 1962-1963).

Em sua relação com o Outro, o sujeito, que depende desse Outro, inscrevese como resultado de uma divisão. Ele é marcado pelos significantes no campo do Outro e, como resultado dessa divisão, há um resto. Esse resto é o objeto $a$. Lacan aborda o objeto $a$ voz como resto quando fala da voz na fita do gravador.

\footnotetext{
Trata-se, em outras palavras, da constituição do $a$ como resto. Seja como for, esse fenômeno, quando as condições são realmente as que lhes descrevi, nós só o temos em estado de resto, quer dizer, na fita do gravador. Caso contrário, temos no máximo um murmúrio longínquo, sempre pronto a se interromper à nossa aparição. Será que isso não nos leva a considerar que desse modo nos é oferecido um caminho para apreender que, quanto ao sujeito em vias de se constituir, é exatamente do lado de uma voz desligada de seu suporte que devemos procurar o resto? (Lacan, 1962-1963, p. 298).
}

A voz ouvida pelo gravador não é a mesma do sujeito que a gravou. Ela é estranha. Aquilo que existe entre a voz gravada no gravador e a voz do sujeito é o objeto $a$. Não é possível assimilar essa diferença. A experiência ao ouvir a voz no gravador é de pertencimento quanto àquela voz, mas de maneira estranha, pois se tem a sensação de que falta alguma coisa para que o sujeito reconheça essa voz como completamente sua. Isso que falta é o resto, é o objeto $a$ voz.

A voz responde ao que é dito, mas não pode responder por isso. Em outras palavras, para que ela responda, devemos incorporar a voz como alteridade do que é dito. É por isso mesmo, e não por outra coisa, que, separada de nós nossa voz nos soa como um som estranho. É próprio da estrutura do Outro constituir um certo vazio, o vazio de sua falta de garantia (Lacan, 1962-1963, p. 300).

O estranhamento para com a nossa própria voz é causado pelo objeto $a$ voz, resto da operação de incorporação da voz do Outro como alteridade do que é dito.

\section{OBJETO $A$ VOZ: PRESENÇA E AUSÊNCIA}

O objeto $a$, portanto, pode se apresentar na experiência como ausente ou presente. Em sua ausência, excluído da subjetividade e, por isso, sustentando-a, o objeto a garante o espaço vital da separação do Outro. Aqui, ele carrega as 
características do lixo, do resto. Assim, como excluído, o objeto a sustenta a cena estando fora dela.

Como vimos, faz-se necessário para que o sujeito venha a falar que este seja banhado pela voz do Outro, pois, antes disso, nada era o sujeito, nada ele falava e nem uma voz tinha. Nesse tempo, o da alienação, a sua voz não é sentida como própria pelo sujeito, pois ela não o pertence, mas sim ao Outro.

Como então a voz, já que ela vem do Outro, será sentida como não tanto do Outro, mas como também do sujeito? Esse acontecimento ocorrerá a partir da operação de separação, quando não todo o sujeito passar por essa voz. Quando a voz imposta pelo Outro ao sujeito não compreender todo o sujeito, ou seja, quando restar alguma coisa do sujeito que não passar por essa voz, este tomará a voz como própria.

Isso que restou do sujeito, tornando-o não todo compreendido pela voz imposta pelo Outro e fazendo o sujeito tomar a voz como sua, é o objeto $a$ voz. O objeto $a$ voz, como excluído, é o que garante a tomada da voz e da fala do Outro pelo sujeito como própria, fundando-o, por meio da separação.

O contorno do sujeito oferecendo-lhe modelo e direção foi dado pelo ideal do eu, por meio da saída do complexo de Édipo, das identificações que este engendra e por meio da incorporação da voz do Outro. Aqui a voz aparece como encaixada no imaginário e no ideal. Essa voz só se sustenta com a exclusão do objeto $a$ voz.

É como presença que o objeto $a$ voz perturba a cena. Sua presença desfaz os limites estabelecidos. O sujeito perde os seus limites e as identificações bem estabelecidas, já que agora o Outro é inteiro e sabe tudo sobre o sujeito, não portando nenhuma falta e nem espaço que o separa do sujeito, levando-o a mergulhar em angústia, como afirma Vieira (2012):

Estes objetos especiais, sustentáculos da diferença entre o próprio e o não próprio, são chamados por Lacan de objeto $a$. Apesar de estabelecerem um espaço mediano, não são mediadores, não são meio-termo. [ . . .] apenas recalcados, fora de cena, eles farão seu ofício, pois uma vez presentes, mesmo causando nojo, mesmo desencaixados, podem vir a ser reapropriados pelo Outro, desfazendo o espaço vital de separação que sustentavam e gerando angústia (p. 55).

Logo, o objeto $a$ voz como presença apresenta-se como uma presença difusa, pois a voz que antes era sentida pelo sujeito como própria pode ser reapropriada pelo Outro. Não é à toa que Lacan utiliza como ilustração as vozes perdidas da psicose. 
É com o conceito de objeto $a$ voz como presença que podemos mostrar como a relação que o sujeito estabelece com o supereu é sem identificação e, por isso, Lacan apresenta o supereu como o imperativo do gozo, uma voz que ordena o gozo, sem corpo, sem contorno, uma exigência impessoal, desvinculada de qualquer sustentáculo identificatório. Já o ideal do eu é apresentado como uma exigência vinculada a uma identificação, como ocorre com a saída do menino no Édipo, o que implica na incorporação da voz. Mas, o que é essa voz que ordena o gozo? Essa voz que diz "goza" é o objeto $a$ voz como presença, ou seja, a presença do Outro sob a forma vocal maciça, experimentada como uma "Voz como imperativo, como aquela que reclama obediência ou convicção" (Lacan, 1962-1963, p. 300).

Por isso podemos considerar a emergência do objeto $a$ voz como uma experiência com uma voz como imperativo interrompido que reclama obediência, mas não obediência que deixa margem para qualquer tipo de questionamento à ordem feita. A obediência requerida pela emergência do objeto $a$ voz é uma obediência convicta, o sujeito não se questiona sobre ela apenas a cumpre. Uma voz difusa e sem contorno que não se sabe de onde vem. Experimentada como um acontecimento que toma o sujeito por completo, a voz como imperativo é sentida em todas as direções apresentando especificidade, potência e a possibilidade para abertura a mudanças e ressignificações nos valores do sujeito.

\section{CONSIDERAÇÕES FINAIS}

Neste trabalho, fizemos um breve percurso apresentando o conceito de supereu nas teorias de Freud e Lacan. Vimos, primeiramente, que Lacan marca uma diferença precisa entre supereu e ideal do eu. Pinçamos tal diferença, a partir da identificação necessária à saída do complexo de Édipo.

Para sair do complexo de Édipo, o menino estabelece uma identificação com o obstáculo à realização dos desejos edipianos, ou seja, estabelece uma identificação com o pai como portador do falo, fazendo emergir uma identificação, um modelo que direciona seu gozo, normatizando-o. Essa identificação que direciona o gozo do menino fixar-se-á como um modelo. Lacan chama essa identificação, responsável pela saída do Édipo, de ideal do eu. É o ideal do eu, modelo e identificação com o pai que porta o falo que permitirá ao menino sair da relação de alienação com a mãe e habitar o campo do simbólico.

Assim, aquilo a que Freud designa como herdeiro do complexo de Édipo chamamos ideal do eu. O que é então o supereu? O supereu, para Lacan, é aquilo que representa exatamente o que o complexo de Édipo não recobre em termos de identificação e normatização, pois Édipo fracassa em alguma medida. 
Isso que não é recoberto pela identificação herdeira do Édipo, ou seja, isso que não é recoberto pelo ideal do eu não passou despercebido a Freud e já é apontado por ele quando, por exemplo, fala em uma instância crítica na melancolia que envolve uma identificação mais primitiva que as identificações do ideal do eu.

O supereu, que tinha sua gênese localizada a partir do Édipo, pode agora ser considerado resultado de identificaçôes primárias, arcaico e responsável pela constituição do sujeito primordial, podendo ser tomado como núcleo do próprio eu. Por isso o supereu não pode ser reduzido ao campo das identificações. Isso levou muitos autores a afirmar que o supereu é materno, precoce ou primitivo.

Com Lacan, afirmamos que as adjetivações do supereu como materno ou primitivo nada têm a ver com esse ser maternal ou vir primeiro na constituição do aparato psíquico, mas sim que o supereu não está referido à identificação fálica que dirige e contorna o sujeito.

Apresentamos como Lacan dá certa independência a esse supereu, com relação ao ideal do eu, assim como Freud. Isso foi abordado por meio da noção de supereu como objeto $a$ voz e imperativo. Aproximamos então o supereu e seus imperativos interrompidos do objeto $a$ voz, ambos se apresentando como voz imperativa que reclama obediência e submissão.

Por fim, o supereu, especialmente no sentido de Lacan, apreende-se, sobretudo, como um imperativo interrompido, uma exigência. Para deixar isso bastante explícito, Lacan propõe uma formulação desse imperativo interrompido que, por isso, é sem conteúdo, já que não há identidade nem identificação, por meio da seguinte afirmação: "Nada força ninguém a gozar, senão o supereu. O supereu é o imperativo do gozo - Goza!” (Lacan, 1972-1973/2008, p. 11). 


\section{REFERÊNCIAS}

Barros, R. R. (1997). Eu ideal, ideal do eu e o resto. Latusa, 1,19-33.

Freud, S. (1914). Introdução ao narcisismo. In Obras completas (Vol. 12, pp. 14-50). São Paulo: Companhia da Letras, 2010. (Publicado originalmente em 1914).

Freud, S. (1915). Luto e melancolia. In Obras completas (Vol. 12, pp. 170-194). São Paulo: Companhia da Letras, 2010. (Publicado originalmente em 1915).

Freud, S. (1923). O Eu e o Id. In L. A. Hanns (Trad.), Obras psicológicas de Sigmund Freud (Vol. 3, pp. 27-71). Rio de Janeiro: Imago, 2007. (Publicado originalmente em 1923).

Freud, S. (1933). A dissecação da personalidade psíquica. In Obras completas (Vol. 18, pp. 192-223). São Paulo: Companhia da Letras, 2010. (Publicado originalmente em 1933).

Gerez-Ambertín, M. (2003). As vozes do supereu. Caxias do Sul: Educs.

Lacan, J. (1953-1954). O seminário, livro 1: os escritos técnicos de Freud. Rio de Janeiro: Jorge Zahar, 1986. (Publicado originalmente em 1953-1954).

Lacan, J. (1957-1958). O seminário, livro 5: as formaçôes do inconsciente. Rio de Janeiro: Jorge Zahar, 1999. (Publicado originalmente em 1957-1958).

Lacan, J. (1962-1963). O seminário, livro 10: a angústia. Rio de Janeiro: Jorge Zahar, 2005. (Publicado originalmente em 1962-1963).

Lacan, J. (1964). O seminário, livro 11: os quatros conceitos fundamentais da psicanálise. Rio de Janeiro: Jorge Zahar, 2008. (Publicado originalmente em 1964).

Lacan, J. (1972-1973). O seminário, livro 20: mais, ainda. Rio de Janeiro: Jorge Zahar, 2008. (Publicado originalmente em 1972-1973).

Laplanche, J. \& Pontalis, J. B. (2001). Vocabulário da psicanálise. (4a ed.). São Paulo: Martins Fontes.

Miller, J-A. (2013). Jacques Lacan e a voz. Opção Lacaniana, 4(11). Recuperado a partir de http://www.opcaolacaniana.com.br/pdf/numero_11/voz.pdf

Rudge, A. M. (2006). Pulsão de morte como efeito de Supereu. Ágora, 9(1), 


\section{9-89.}

Valas, P. (2001). As dimensões do gozo: do mito da pulsão à deriva do gozo. Rio de Janeiro: Jorge Zahar.

Vieira, M. A. (2008). Restos: uma introdução lacaniana o objeto da psicanálise. Rio de Janeiro: Contra Capa.

Vieira, M. A. (2012). A paixão. Rio de Janeiro: Jorge Zahar. 